Original research article

Food Quality and Functionality Section

\title{
Effect of Lecithin and Mono- and Di-Glycerides on Quality and Shelf Life of Hazelnut Butter: Chemometric Approach
}

\author{
Amir Pourfarzad ${ }^{1 *}{ }^{\circledR}$, Rezvaneh Shokouhi Kisomi ${ }^{2}$ \\ ${ }^{1}$ Department of Food Science and Technology, Faculty of Agricultural Sciences, University of Guilan, Rasht, Iran \\ ${ }^{2}$ Department of Food Science, Rasht Branch, Islamic Azad University, Rasht, Iran
}

Key words: texture analysis, sensory evaluation, lecithin, hazelnut, mono- and di-glyceride

Nut butter can be recognized as a functional food substitute for the animal butter. This study aimed to investigate the effects of mono- and di-glycerides and lecithin on the physicochemical properties and sensory characteristics of hazelnut butter. For this purpose, mono- and di-glycerides, and lecithin were employed in the hazelnut butter formulation at 0,1 , and $2 \mathrm{~g} / 100 \mathrm{~g}$ addition levels. The proximate composition, acidity, peroxide value, and texture parameters were evaluated. Although adding mono- and di-glycerides and lecithin to the hazelnut butter formulation did not significantly change the adhesiveness, it increased their hardness. The sensory analysis revealed that lecithin and mono- and di-glycerides did not significantly affect the color, taste, and flavor of the butters. The highest texture, spreadability, and overall acceptance scores were observed when lecithin was used at the level of $2 \mathrm{~g} / 100 \mathrm{~g}$. The lowest acidity had butter containing mono- and di-glycerides at the level of $1 \mathrm{~g} / 100 \mathrm{~g}$. The peroxide values showed no significant changes during the 90-day storage. The principal component analysis (PCA) allowed discriminating among the features. The partial least squares regression (PLSR) models were applied to find the relationship between sensory and instrumental data. Thus, chemometric approach appears to be a promising technique for the analysis of hazelnut butter.

\section{INTRODUCTION}

Hazelnut (Corylus avellana L.) is a shrub belonging to the Fagales order from the Betulaceae family and Coryluideae sub-family. By monitoring the regular development of nuts in the last five years, the global hazelnut-cultivated area greatly increased beyond 670,000 ha in 2017 [FAOSTAT, 2020]. Also, the hazelnut cultivation has recently extended beyond the native areas, namely Europe and West Asia [Ascari et al., 2020].

Hazelnuts can be a valuable component of a human diet due to their special nutritional value [Pourfarzad \& Mehrpour, 2017]. Hazelnut kernels are important sources of tocopherols and water-soluble B-vitamins, as well as minerals [Capurso et al., 2018; Stuetz et al., 2017]. According to the daily microelement requirements, $100 \mathrm{~g}$ of hazelnut provide about $50 \%$ for $\mathrm{Fe}, 41 \%$ for Mo, $32 \%$ for $\mathrm{Zn}, 21 \%$ for Se, and $21 \%$ for $\mathrm{Cr}$ [Turan \& Akccedil, 2011]. A hazelnut-rich diet can also easily improve a daily intake of $\mathrm{Mn}, \mathrm{Cu}$, and Co. The oil is a major component of hazelnut kernels (50-73 g/100 g) [Garcia et al., 1994]. It contains mainly unsaturated fatty acids, i.e., oleic and linoleic acids, while saturated fatty acids (palmitic and steric acids) constitute only $\sim 9 \%$ of its total fatty acids [Taş \& Gökmen, 2015]. Given

\footnotetext{
* Corresponding Author: Tel.: +98-13-33690282; Fax: +98-13-33690281;

E-mail: amir.pourfarzad@gmail.com
}

the unique fatty acid profile, hazelnut can protect low-density lipoproteins against oxidation and thus prevent the development of the cardiovascular disease [Ros, 2010]. Hazelnut oil contains $\beta$-sitosterol, a natural plant sterol recognized to reduce cholesterol levels and defend against different types of cancer such as breast, colon, and prostate cancers [Akcicek et al., 2005]. The protein content of hazelnut kernel changes between 10 and $22 \mathrm{~g} / 100 \mathrm{~g}$ [Taş \& Gökmen, 2018]. Hazelnuts are a popular and important source of high-quality vegetable protein in vegetarian diets, where they rank high on the list of foods most frequently consumed, above meat substitutes. They have a high content of L-arginine. This amino acid is the precursor of the endogenous vasodilator (nitric oxide), and might help improve vascular reactivity [Huynh \& Chin-Dusting, 2006]. Hazelnuts are also a good source of dietary fiber $(10.4 \mathrm{~g} / 100 \mathrm{~g}$ ) [Ros, 2010].

Nut butter is one of the nut processing products that is obtained by milling the roasted kernels and mixing them with a small amount of sugar. It can be considered as a substitute for animal butter to be used as a breakfast food and also in different food products such as cookies, ice creams, and cakes [Dobhal et al., 2018]. Nowadays, the hazelnut processing is of great importance due to the limited use of hazelnut in its raw form and the continuous increase in the number of hazelnut gardens. One of the possibilities for wider food use of hazelnuts is the production of hazelnut butter. In other words, butter can be a good new product for consumers to increase the consumption of highly 
nutritious hazelnuts. The formulation of hazelnut butter is the first step in commercializing this product. The intrinsic tendency of various phases to separate is an undesirable phenomenon in food products such as chocolates and nut butters and spreads. It needs to be eliminated using different processing operations and proper additives [Ardakani et al., 2009; Villarroel et al., 1993].

Emulsifiers are a wide class of additives that are employed in the food industry to improve the quality and prolong the shelf life of products [Pourfarzad et al., 2012, 2014, 2019; Pourfarzad \& Habibi-Najafi, 2012]. They allow two different phases to combine and form a semi-homogenous and stable mixture that can last for a long time. Moreover, the addition of an emulsifier increases product tolerance to high temperature. Thus, it seems crucial to evaluate the effect of this type of additives on the hazelnut butter properties. The mono- and di-glycerides and lecithin are commonly used as emulsifiers. They were recently successfully applied in chocolate spread emulsion and cheese analogue obtained from raw peanut [Eudier et al., 2020; Said et al., 2019].

To the best of our knowledge, a limited number of studies have addressed the impact of emulsifiers on the quality and shelf life of hazelnut butter. Therefore, the present study aimed to investigate the effect of emulsifiers on the physicochemical and sensory properties of hazelnut butter. In the next step, the correlation between different features of hazelnut butter was evaluated using symmetric multivariate methods, such as correlation analysis and principal component analysis (PCA), and asymmetric method like partial least squares regression (PLSR).

\section{MATERIALS AND METHODS}

\section{Materials}

Raw hazelnuts (without outer shell) were provided from Eshkevarat (Rudsar, Guilan, Iran). Mono- and di-glycerides (CREMODAN $®$ Super Mono-diglyceride) and lecithin (catalogue number 429415) were supplied from Danisco (Copenhagen, Denmark) and Merck (Darmstadt, Germany) Companies, respectively. All other chemicals, reagents, and solvents were of analytical grade.

\section{Hazelnut butter production}

The raw hazelnuts were roasted in a solar dome convection system (model 3855SCR, LG Company, Seul, South Korea) for $20 \mathrm{~min}$ at $150^{\circ} \mathrm{C}$ [Pourfarzad et al., 2016, 2018]. After cooling down, the brown skin was manually peeled off using a rough cloth, and the butter production was conducted by a nut butter mill made by Niri Organic Yazd (model N1, Yazd, Iran). Two batches were processed for each treatment and one batch contained $1 \mathrm{~kg}$ of hazelnuts. Then, $10 \mathrm{~g} / 100 \mathrm{~g}$ of sugar was added to the prepared butter and kneaded to provide soft dough. In this step, the specified amounts of mono- and di-glyceride $(0,1,2 \mathrm{~g} / 100 \mathrm{~g})$ and lecithin $(0,1,2 \mathrm{~g} / 100 \mathrm{~g})$ were added to the hazelnut butter. The treatment levels were chosen by carrying out preliminary screening tests according to the literature reports and instrumental aspects.

\section{Proximate composition analysis}

The contents of moisture (926.12), ash (950.49), protein (955.04C), fat (922.06), total dietary fiber (978.10), and total sugars (984.22), as well as acidity (962.12) and peroxide value (965.33) were analyzed by the Association of Official Analytical Chemists (AOAC) methods [2005].

\section{Texture analysis}

The penetration test was conducted on 200-gram samples of butter to evaluate hardness and adhesiveness. For this purpose, a Brookfield texture analyzer (CT3, Middleboro, MA, United States) was employed, and the force required for the penetration of a thick elliptical bar probe with a flat cross-section and diameter of $0.48 \mathrm{~cm}$ (velocity of $200 \mathrm{~mm} / \mathrm{min}$ and penetration depth of $1 \mathrm{~cm}$ ) was determined [Ardakani et al., 2009].

\section{Sensory evaluation}

Ten trained panelists of both genders aged from 25 to 60 evaluated the hazelnut butter samples. All assessors of the internal sensory panel have undertaken the basic flavor test, odor test, and color vision test. They have been trained for sensory methods in several sessions and their evaluation aptitude has been routinely checked. The panel was particularly familiarized with the score of attribute intensities using the verbal meanings describing the ends of the intensity scales of the characteristics. Each sample contained $30 \mathrm{~g}$ of hazelnut butter, which were given to panelists in plastic containers at room temperature. The taste, flavor, texture, color, spreadability, and overall acceptance were assessed. Each parameter was scored in a 5-point scaling range from 1 (lowest) to 5 (highest) [Ardakani et al., 2009; Qaziyani et al., 2019].

\section{Oil separation}

The oil was collected using a Pasteur pipette, moved to a 50-mL graduated cylinder, and its volume was determined. The oil separation rate was calculated as follows [Gills \& Resurreccion, 2000a]:

Oil separation $(\%)=($ Volume of oil separated $) /$

(Volume of hazelnut butter before oil separation) $\times 100$

\section{Shelf life test}

To determine the product shelf life, acidity, peroxide value, and oil separation of the samples were evaluated during 90-day storage at $25^{\circ} \mathrm{C}$ [AOAC, 2005; Ardakani et al., 2009].

\section{Statistical analysis}

The data on the physicochemical properties and sensory characteristics of hazelnut butter with and without emulsifiers were statistically analyzed. To investigate the significant difference between the means, the Duncan's multiple range test was carried out after the analysis of variance at the $95 \%$ confidence level. Each experiment was performed in six replications. The Pearson's correlation analysis, PCA, and PLSR modeling were performed on the data sets. The data analyses were taken using Minitab 15 (Minitab Inc., State College, PA, USA). 


\section{RESULTS AND DISCUSSION}

\section{Proximate composition of hazelnut butter}

The contents of moisture, fat, protein, dietary fiber, total sugars, and ash of the control hazelnut butter (without emulsifiers) were as follows: $0.76 \pm 0.00,59.09 \pm 0.21,15.68 \pm 0.01$, $5.51 \pm 0.12,15.88 \pm 0.23$, and $2.21 \pm 0.06 \mathrm{~g} / 100 \mathrm{~g}$, respectively. A daily intake of $25 \mathrm{~g}$ of hazelnuts is recommended in a healthy diet [Stuetz et al., 2017], which nearly corresponds to the standard portion size of $1 \mathrm{oz}(28.35 \mathrm{~g})$ displayed by the United States Department of Agriculture [USDA, 2015]. Based on this recommendation, it can be concluded that hazelnut butter could provide $3 \%, 17 \%, 53 \%$, and $22 \%$ of the daily dietary requirement for carbohydrates, proteins, fat, and dietary fiber, respectively.

\section{Texture analysis}

The results of instrumental texture analysis of hazelnut butters are shown in Table 1. The addition of lecithin and monoand di-glycerides increased the hardness of the butters, although no significant difference $(p>0.05)$ was observed between hardness of the samples with different contents of emulsifiers ( 1 and $2 \mathrm{~g} / 100 \mathrm{~g}$ ). The higher hardness of butters with additives compared to the control one can be attributed to the hydrophilicity of lecithin and mono- and di-glycerides. They can strengthen the network structure of butter solids, which leads to the stabilization of oil in it [Totlani \& Chinnan, 2007]. The development of this network resulted in the greater energy required for the probe penetration during the texture analysis. Also, the interactions between emulsifiers and hazelnut biopolymers produce large internal frictions and, as a result, higher hardness [Izidoro et al., 2009].

Adhesiveness was determined as the work required to pull the probe away from the sample in the penetration test. The values of this parameter for hazelnut butters ranged from 1.18 to $1.25 \mathrm{~N} \cdot \mathrm{s}$ (Table 1). However, no significant differences $(p>0.05)$ were found between adhesiveness of the control samples and the butters containing emulsifiers. The level of both lecithin and mono- and di-glycerides added also did not significantly differentiate the adhesiveness of the butters.

\section{Sensory evaluation}

Table 2 shows the results of the sensory analysis of hazelnut butters. The taste, flavor, and color scores of the control sample were not significantly different from those containing various levels of lecithin and mono- and di-glycerides $(p>0.05)$. As one of the dominant features in consumers' food preferences, the sensory texture plays a key role in product attractiveness, purchasing decisions, and ultimate consumption [Pellegrino et al., 2020]. Adding lecithin to the hazelnut butter formulation increased the texture score of the samples from 3.67 (control butter) to 4.36 (butter with $2 \mathrm{~g} / 100 \mathrm{~g}$ addition level). In the case of adding the second emulsifier, although there was no significant difference between the texture scores of the control sample and butter with mono- and di-glycerides at level of $1 \mathrm{~g} / 100 \mathrm{~g}(p>0.05)$, the sample with a higher content of mono- and di-glycerides $(2 \mathrm{~g} / 100 \mathrm{~g})$ showed a significantly higher texture score $(p \leq 0.05)$. Spreadability is a particularly important characteristic of semi-solid food texture. It is a subjective term linked to the way a sample is uniformly distributed over a surface [Gills \& Resurreccion, 2000b]. In our study, upon the addition of mono- and di-glyceride to butter, its spreadability was assessed by panelists as significantly better $(p \leq 0.05)$ than that of the control sample, although no significant difference $(p>0.05)$ was observed between the spreadability of products with different contents of mono- and di-glycerides ( 1 and $2 \mathrm{~g} / 100 \mathrm{~g}$ ). The sample containing lecithin at $2 \mathrm{~g} / 100 \mathrm{~g}$ showed higher spreadability than the control and butter with additive of $1 \mathrm{~g} / 100 \mathrm{~g}$. The trends

TABLE 1. Texture parameters of hazelnut butters with different contents of emulsifiers.

\begin{tabular}{l|c|c|c}
\hline Emulsifier & $\begin{array}{c}\text { Additive level } \\
(\mathrm{g} / 100 \mathrm{~g})\end{array}$ & $\begin{array}{c}\text { Hardness } \\
(\mathrm{N})\end{array}$ & $\begin{array}{c}\text { Adhesiveness } \\
(\mathrm{N} \cdot \mathrm{s})\end{array}$ \\
\hline & 0 & $5.45 \pm 0.023^{\mathrm{b}}$ & $1.15 \pm 0.082^{\mathrm{a}}$ \\
Lecithin & 1 & $5.72 \pm 0.041^{\mathrm{a}}$ & $1.21 \pm 0.045^{\mathrm{a}}$ \\
& 2 & $5.81 \pm 0.078^{\mathrm{a}}$ & $1.18 \pm 0.324^{\mathrm{a}}$ \\
$\begin{array}{l}\text { Mono- } \\
\text { and } \\
\text { di-glycerides }\end{array}$ & 0 & $5.48 \pm 0.043^{\mathrm{b}}$ & $1.21 \pm 0.012^{\mathrm{a}}$ \\
& 1 & $5.72 \pm 0.067^{\mathrm{a}}$ & $1.08 \pm 0.213^{\mathrm{a}}$ \\
\hline
\end{tabular}

Each value is a mean \pm standard deviation of three experimental replicates $(n=6)$. Values in columns with different letters are significantly different $(\mathrm{p} \leq 0.05)$.

TABLE 2. Sensory characteristics of hazelnut butters with different contents of emulsifiers.

\begin{tabular}{lcccccc|c}
\hline Emulsifier & $\begin{array}{c}\text { Additive level } \\
(\mathrm{g} / 100 \mathrm{~g})\end{array}$ & Taste & Flavor & Texture & Color & Spreadability & $\begin{array}{c}\text { Overall } \\
\text { acceptance }\end{array}$ \\
\hline \multirow{3}{*}{ Lecithin } & 0 & $3.23 \pm 0.232^{\mathrm{a}}$ & $3.67 \pm 0.322^{\mathrm{a}}$ & $3.31 \pm 0.032^{\mathrm{c}}$ & $4.03 \pm 0.434^{\mathrm{a}}$ & $3.43 \pm 0.032^{\mathrm{b}}$ & $3.21 \pm 0.031^{\mathrm{b}}$ \\
& 1 & $3.63 \pm 0.427^{\mathrm{a}}$ & $3.73 \pm 0.544^{\mathrm{a}}$ & $3.81 \pm 0.201^{\mathrm{b}}$ & $4.01 \pm 0.656^{\mathrm{a}}$ & $3.77 \pm 0.034^{\mathrm{ab}}$ & $3.63 \pm 0.033^{\mathrm{a}}$ \\
& 2 & $3.67 \pm 0.432^{\mathrm{a}}$ & $3.87 \pm 0.004^{\mathrm{a}}$ & $4.36 \pm 0.203^{\mathrm{a}}$ & $4.01 \pm 0.646^{\mathrm{a}}$ & $3.97 \pm 0.012^{\mathrm{a}}$ & $4.03 \pm 0.042^{\mathrm{a}}$ \\
Mono- & 0 & $3.37 \pm 0.433^{\mathrm{a}}$ & $3.60 \pm 0.444^{\mathrm{a}}$ & $3.67 \pm 0.009^{\mathrm{b}}$ & $4.13 \pm 0.322^{\mathrm{a}}$ & $3.33 \pm 0.101^{\mathrm{b}}$ & $3.53 \pm 0.009^{\mathrm{b}}$ \\
$\begin{array}{l}\text { and } \\
\text { di-glycerides }\end{array}$ & 1 & $3.37 \pm 0.302^{\mathrm{a}}$ & $3.80 \pm 0.323^{\mathrm{a}}$ & $3.57 \pm 0.101^{\mathrm{b}}$ & $3.91 \pm 0.111^{\mathrm{a}}$ & $3.81 \pm 0.323^{\mathrm{a}}$ & $3.33 \pm 0.004^{\mathrm{b}}$ \\
& 2 & $3.81 \pm 0.109^{\mathrm{a}}$ & $3.87 \pm 0.632^{\mathrm{a}}$ & $4.11 \pm 0.201^{\mathrm{a}}$ & $4.01 \pm 0.564^{\mathrm{a}}$ & $4.03 \pm 0.077^{\mathrm{a}}$ & $4.01 \pm 0.005^{\mathrm{a}}$ \\
\hline
\end{tabular}

Each value is a mean \pm standard deviation of three experimental replicates $(n=6)$. Values in columns with different letters are significantly different $(\mathrm{p} \leq 0.05)$. 
TABLE 3. Acidity (g oleic acid/100 g) of hazelnut butters with different contents of emulsifiers during storage.

\begin{tabular}{|c|c|c|c|c|c|}
\hline \multirow{2}{*}{ Emulsifier } & \multirow{2}{*}{ Additive level (g/100 g) } & \multicolumn{4}{|c|}{ Storage time (day) } \\
\hline & & 1 & 30 & 60 & 90 \\
\hline \multirow{3}{*}{ Lecithin } & 0 & $0.28 \pm 0.003^{\mathrm{a}}$ & $0.48 \pm 0.005^{\mathrm{a}}$ & $0.56 \pm 0.003^{\mathrm{a}}$ & $0.59 \pm 0.005^{\mathrm{a}}$ \\
\hline & 1 & $0.28 \pm 0.003^{\mathrm{a}}$ & $0.42 \pm 0.006^{\mathrm{b}}$ & $0.53 \pm 0.005^{b}$ & $0.55 \pm 0.003^{b}$ \\
\hline & 2 & $0.28 \pm 0.004^{a}$ & $0.41 \pm 0.004^{\mathrm{c}}$ & $0.42 \pm 0.001^{\mathrm{c}}$ & $0.47 \pm 0.021^{\mathrm{c}}$ \\
\hline \multirow{3}{*}{$\begin{array}{l}\text { Mono- } \\
\text { and } \\
\text { di-glycerides }\end{array}$} & 0 & $0.28 \pm 0.003^{\mathrm{a}}$ & $0.46 \pm 0.002^{\mathrm{b}}$ & $0.54 \pm 0.018^{\mathrm{b}}$ & $0.59 \pm 0.002^{\mathrm{b}}$ \\
\hline & 1 & $0.28 \pm 0.002^{\mathrm{a}}$ & $0.38 \pm 0.003^{c}$ & $0.37 \pm 0.022^{\mathrm{c}}$ & $0.45 \pm 0.001^{\mathrm{c}}$ \\
\hline & 2 & $0.28 \pm 0.004^{a}$ & $0.47 \pm 0.002^{\mathrm{a}}$ & $0.60 \pm 0.005^{\mathrm{a}}$ & $0.63 \pm 0.011^{\mathrm{a}}$ \\
\hline
\end{tabular}

Each value is a mean \pm standard deviation of three experimental replicates $(n=6)$. Values in columns with different letters are significantly different $(\mathrm{p} \leq 0.05)$.

TABLE 4. Peroxide value (meq/kg) of hazelnut butters with different contents of emulsifiers during storage.

\begin{tabular}{|c|c|c|c|c|c|}
\hline \multirow{2}{*}{ Emulsifier } & \multirow{2}{*}{ Additive level $(\mathrm{g} / 100 \mathrm{~g})$} & \multicolumn{4}{|c|}{ Storage time (day) } \\
\hline & & 1 & 30 & 60 & 90 \\
\hline \multirow{3}{*}{ Lecithin } & 0 & $0.08 \pm 0.003^{\mathrm{a}}$ & $0.09 \pm 0.004^{\mathrm{a}}$ & $0.16 \pm 0.002^{\mathrm{a}}$ & $0.19 \pm 0.014^{\mathrm{a}}$ \\
\hline & 1 & $0.08 \pm 0.002^{\mathrm{a}}$ & $0.09 \pm 0.004^{\mathrm{a}}$ & $0.16 \pm 0.003^{\mathrm{a}}$ & $0.19 \pm 0.014^{\mathrm{a}}$ \\
\hline & 2 & $0.08 \pm 0.001^{\mathrm{a}}$ & $0.09 \pm 0.006^{\mathrm{a}}$ & $0.16 \pm 0.004^{\mathrm{a}}$ & $0.19 \pm 0.024^{\mathrm{a}}$ \\
\hline \multirow{3}{*}{$\begin{array}{l}\text { Mono- } \\
\text { and } \\
\text { di-glycerides }\end{array}$} & 0 & $0.08 \pm 0.002^{\mathrm{a}}$ & $0.09 \pm 0.006^{\mathrm{a}}$ & $0.16 \pm 0.015^{\mathrm{a}}$ & $0.19 \pm 0.016^{\mathrm{a}}$ \\
\hline & 1 & $0.08 \pm 0.001^{\mathrm{a}}$ & $0.09 \pm 0.006^{\mathrm{a}}$ & $0.16 \pm 0.024^{\mathrm{a}}$ & $0.19 \pm 0.006^{\mathrm{a}}$ \\
\hline & 2 & $0.08 \pm 0.001^{\mathrm{a}}$ & $0.09 \pm 0.006^{\mathrm{a}}$ & $0.16 \pm 0.017^{\mathrm{a}}$ & $0.19 \pm 0.004^{\mathrm{a}}$ \\
\hline
\end{tabular}

Each value is a mean \pm standard deviation of three experimental replicates $(n=6)$. Values in columns with different letters are significantly different $(\mathrm{p} \leq 0.05)$.

of sensory texture and spreadability might be similar due to the effect of emulsifiers on the hardness [Ardakani et al., 2009; Saker Ardakani, 2007]. The addition of lecithin also improved the overall acceptance of the samples, although no significant difference $(p>0.05)$ was observed between butters containing emulsifier at the levels of 1 and $2 \mathrm{~g} / 100 \mathrm{~g}$. The overall acceptance of the butter containing mono- and di-glycerides at $2 \mathrm{~g} / 100 \mathrm{~g}$ was significantly higher $(p \leq 0.05)$ compared to the samples with lower additive contents ( 0 and $1 \mathrm{~g} / 100 \mathrm{~g}$ ). Also, no significant difference $(p>0.05)$ was observed between the scores given to the control sample and butter with mono- and di-glyceride addition at $1 \mathrm{~g} / 100 \mathrm{~g}$.

\section{Shelf life test}

Acidity is one of the major parameters in the quality control of oils and edible fats. Its value may increase as a result of hydrolysis and lipolysis. High acidity is an indicator of the low quality of oil. The oil storage can significantly change the acidity [San Martín et al., 2020]. In our study, the effect of adding emulsifiers to hazelnut butters on their acidity was monitored over the 90-day storage period (Table 3). There were no significant differences $(p>0.05)$ between the acidity of different butters on the first day. Adding lecithin to butter significantly reduced acidity increase during storage. The control butter had significantly higher acidity $(p \leq 0.05)$ than the butters with lecithin at each monitored storage time (30-90 days). Also, the level of the lecithin additive significantly affected the acidity. Our notice is in line with previous studies, in which acidity of a similar product, i.e., pistachio butter, was determined during storage [Haghani Haghighi et al., 2008]. Authors recommend using lecithin as an emulsifier to improve the long-term storage stability of nut butter. The hazelnut batters containing mono- and di-glycerides at levels of $1 \mathrm{~g} / 100 \mathrm{~g}$ and $2 \mathrm{~g} / 100 \mathrm{~g}$ had the lowest and the highest acidity, respectively, at each monitored storage time. In other words, the mono- and diglycerides added at the level of $1 \mathrm{~g} / 100 \mathrm{~g}$ decreased the acidity compared to the control butter, but a higher addition level resulted in acidity increase. This can be attributed to the presence of fatty acids in the chemical structure of mono- and di-glycerides. With the higher level of mono and di-glyceride addition, more products of fatty acid hydrolysis were generated, which led to an increase in product acidity [Mirtajeddini et al., 2016].

The oxidation is the main process of fat spoilage, giving rise to undesirable odor and taste. One of the parameters commonly used to evaluate the state of oxidation of fats and oils is the peroxide value. The changes in the peroxide values during 90-day storage of hazelnut butter are shown in Table 4. As expected, the peroxide values increased during storage. However, at each storage time for which the measurement was taken, the peroxide value of the control butter 
TABLE 5. Oil separation $(\mathrm{mL})$ in hazelnut butters with different contents of emulsifiers during storage.

\begin{tabular}{|c|c|c|c|c|c|}
\hline \multirow{2}{*}{ Emulsifier } & \multirow{2}{*}{ Additive level $(\mathrm{g} / 100 \mathrm{~g})$} & \multicolumn{4}{|c|}{ Storage time (day) } \\
\hline & & 1 & 30 & 60 & 90 \\
\hline \multirow{3}{*}{ Lecithin } & 0 & $0 \pm 0.001^{\mathrm{a}}$ & $5.79 \pm 0.211^{\mathrm{a}}$ & $6.74 \pm 0.054^{\mathrm{a}}$ & $8.42 \pm 0.021^{\mathrm{a}}$ \\
\hline & 1 & $0 \pm 0.001^{\mathrm{a}}$ & $2.65 \pm 0.344^{b}$ & $3.08 \pm 0.031^{\mathrm{b}}$ & $3.85 \pm 0.033^{\mathrm{b}}$ \\
\hline & 2 & $0 \pm 0.001^{\mathrm{a}}$ & $2.11 \pm 0.223^{\mathrm{c}}$ & $2.46 \pm 0.022^{c}$ & $3.07 \pm 0.054$ \\
\hline \multirow{3}{*}{$\begin{array}{l}\text { Mono- } \\
\text { and } \\
\text { di-glycerides }\end{array}$} & 0 & $0 \pm 0.001^{\mathrm{a}}$ & $5.82 \pm 0.213^{\mathrm{a}}$ & $6.77 \pm 0.043^{\mathrm{a}}$ & $8.46 \pm 0.021^{a}$ \\
\hline & 1 & $0 \pm 0.001^{\mathrm{a}}$ & $2.45 \pm 0.321^{b}$ & $2.85 \pm 0.233^{\mathrm{b}}$ & $3.56 \pm 0.021^{\mathrm{b}}$ \\
\hline & 2 & $0 \pm 0.001^{\mathrm{a}}$ & $1.62 \pm 0.175^{\mathrm{c}}$ & $1.88 \pm 0.322^{\mathrm{c}}$ & $2.35 \pm 0.087^{\circ}$ \\
\hline
\end{tabular}

Each value is a mean \pm standard deviation of three experimental replicate experiments $(n=6)$. Values in columns with different letters are significantly different $(\mathrm{p} \leq 0.05)$.

did not differ significantly ( $p>0.05$ ) from the peroxide values of the butters containing lecithin and mono- and di-glycerides at both levels.

Oil separation can be used as an indicator of product structure preservation during storage [Deng et al., 2020]. The oil separation of hazelnut butters with and without emulsifiers during the storage is shown in Table 5. There was no oil separated in any of the samples on the first day of storage experiment. Oil separation increases with storage, but this increase was significantly lower in hazelnut butters with emulsifiers than in the control. The level of additive also affected the oil separation. Oil separation in butters with both emulsifiers added at the level of $1 \mathrm{~g} / 100 \mathrm{~g}$ was significantly higher than that reported for the samples containing $2 \mathrm{~g} / 100 \mathrm{~g}$ at each storage time (30, 60 , or 90 days). This behavior was probably exhibited by the increased intermolecular interactions. The oil was detected as a non-emulsified (free) fluid in the voids between solid particles [Ereifej et al., 2005]. The oil separation is the result of the hazelnut matrix compression. Emulsifiers can immobilize the free oil and prevent its migration [Totlani \& Chinnan, 2007]. The mechanism for avoiding the oil separation seems to be associated with the increased viscosity of the oil phase via hardness increase [Ereifej et al., 2005].

\section{Relationship between physicochemical properties and sensory characteristics of hazelnut butter}

\section{Correlation analysis}

The results of Person's correlations between texture parameters, quality properties at 30-90-day storage, and sensory scores of hazelnut butter are shown in Table 6 . The correlation coefficients ( $r$ ) of significant correlations ranged from -0.487 to 1 . Within the texture parameters, the hardness highly correlated with sensory characteristic scores and oil separation at 30-90-day storage. The harder samples strongly corresponded to those with higher sensory scores of spreadability and texture. As indicated earlier, emulsifiers affect the sensory texture and spreadability due to a change in hardness. Also, the samples with high hardness showed lower oil separation during the storage. This may be due to the oil immobilization effect of emulsifiers [Totlani \& Chinnan, 2007], leading to the increased hardness. Adhesiveness was highly positively correlated with acidity at 30-90-day storage. Within the sensory characteristics, the overall acceptance, spreadability, and flavor scores showed significant correlations with many other properties. The overall acceptance was highly positively correlated with taste and texture. Considering the significant relationships between sensory characteristics and shelf life properties, color and acidity showed positive correlations. Also, the higher the spreadability score, the lower the oil separation. Among the shelf life properties, acidity on the $30^{\text {th }}$ day of storage was significantly correlated with oil separation during the storage. The results show that the sensory and texture analysis can potentially be used to estimate different properties of hazelnut butter. The findings deserve special attention and may have significant potential for optimizing and improving the product quality, shelf life properties, and sensory characteristics as well as for reducing the time and costs by minimizing the experiments.

\section{Principal component analysis}

Sometimes, too many variables are involved in calculations, and the principal component analysis (PCA) helps reducing them to a smaller group. PCA is a factor model in which the factors are based on the total variance, allowing for bargaining the fewest number of variables that clarify the variance [Tipping \& Bishop, 1999]. The data of instrumental texture analysis, sensory analysis and quality of storage experiment of hazelnut butter were subjected to PCA (Figure 1). The multivariate treatment of the data obtained from the samples enabled reducing the variables to two principal components, which together explained $79.6 \%$ of the total variability. The first component (PC1) accounted for 53.7\% and the second component (PC2) for 25.9\%. According to the PCA biplot, hardness, adhesiveness, and sensory characteristics such as overall acceptance, spreadability, texture, flavor, and taste, were negatively correlated to PC1, whereas other hazelnut butter properties were positively correlated to PC1. Hardness, acidity of the fresh butter (1 day of storage experiment), and oil separation during the storage were negatively correlated to PC2, while other butter characteristics and properties were positively correlated to PC2. As clearly revealed in the PCA biplot (Figure 1), the butters with the best sensory scores of overall acceptance, taste, and texture were those 


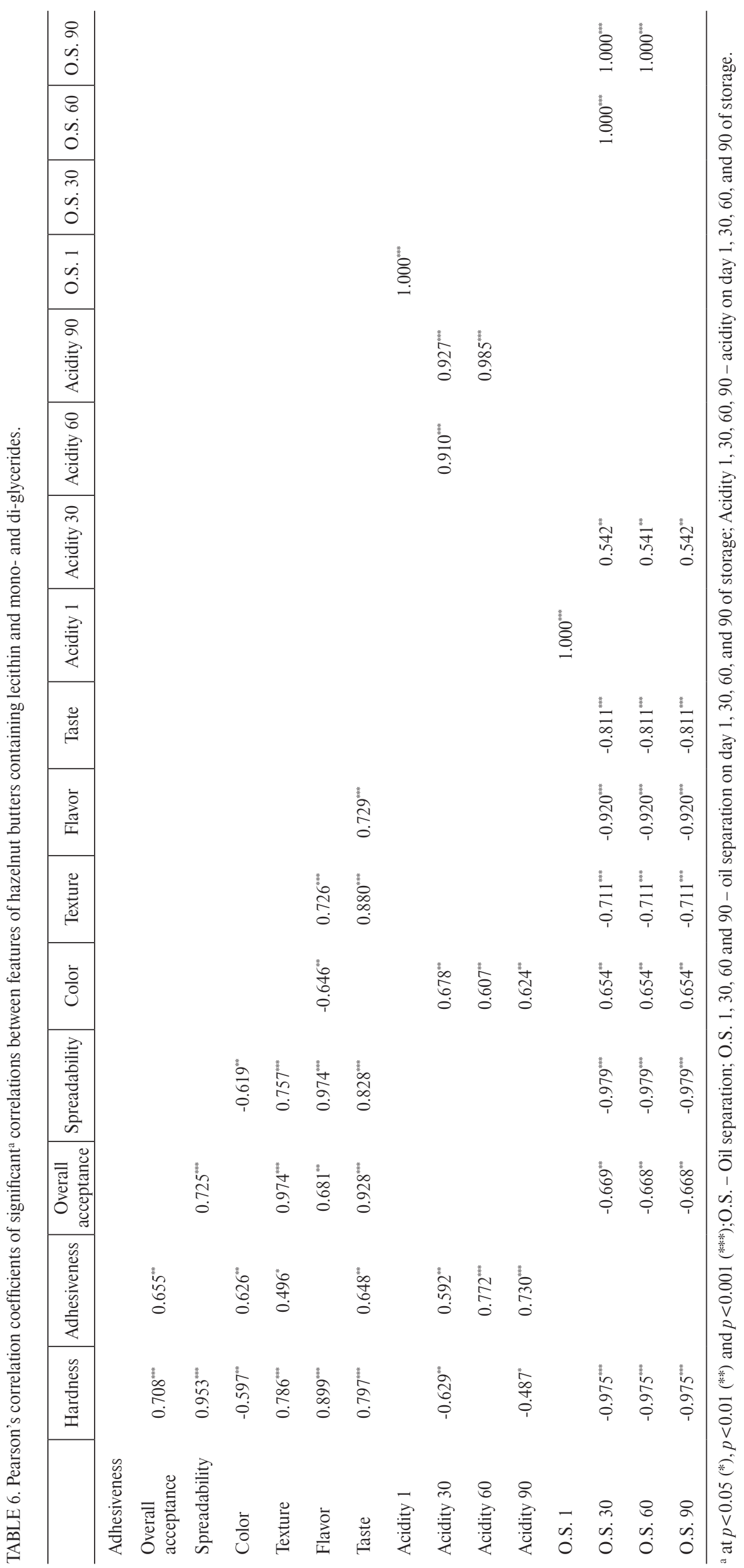


containing mono- and di-glyceride at the level of $2 \mathrm{~g} / 100 \mathrm{~g}$ and lecithin at the level of $1 \mathrm{~g} / 100 \mathrm{~g}$. The results of PCA confirm our previous consideration that the addition of lecithin resulted in a decrease in oil separation during the storage, but increased spreadability, flavor, and hardness, and that the lowest acidity during storage was observed for the sample containing mono- and di-glycerides at the level of $1 \mathrm{~g} / 100 \mathrm{~g}$.

\section{Partial least squares regression}

PLSR is a technique that diminishes the predictors to a smaller series of uncorrelated components and makes least squares regression on the components rather than the original data. For instance, PLSR is often used to establish relationships between instrumental and sensory descriptive data. Based on this technique, the process-checking strategies primarily measure the unrealized variable models to explain the error recognition indices later. Today, such strategies have extraordinary potentials for industrial applications [Godoy et al., 2014; Martens \& Martens, 2001]. Thus, the prediction of sensory characteristics by instrumental dimensions is of supreme importance in the food industry, as it provides much information about the appropriateness and quality of the final product. Several researchers have afforded to correlate various chemical and rheological properties describing the quality and shelf life of different food products with sensory characteristics [Hejri-Zarifi et al., 2013; Pourfarzad et al., 2012; Qaziyani et al., 2019]. Determining the quality profile by instrumental dimensions has the benefits of high convenience, reproducibility, and directness compared to the evaluation of sensory components [Sabanis et al., 2009]. Thus, the instrumental properties with the most significant interrelationships with other properties were used as the predictors. In our study, the instrumental texture parameters (hardness and adhesiveness), acidity and oil separation during storage were used to predict sensory scores of hazelnut butters. The output regression equations are given in Table 7.
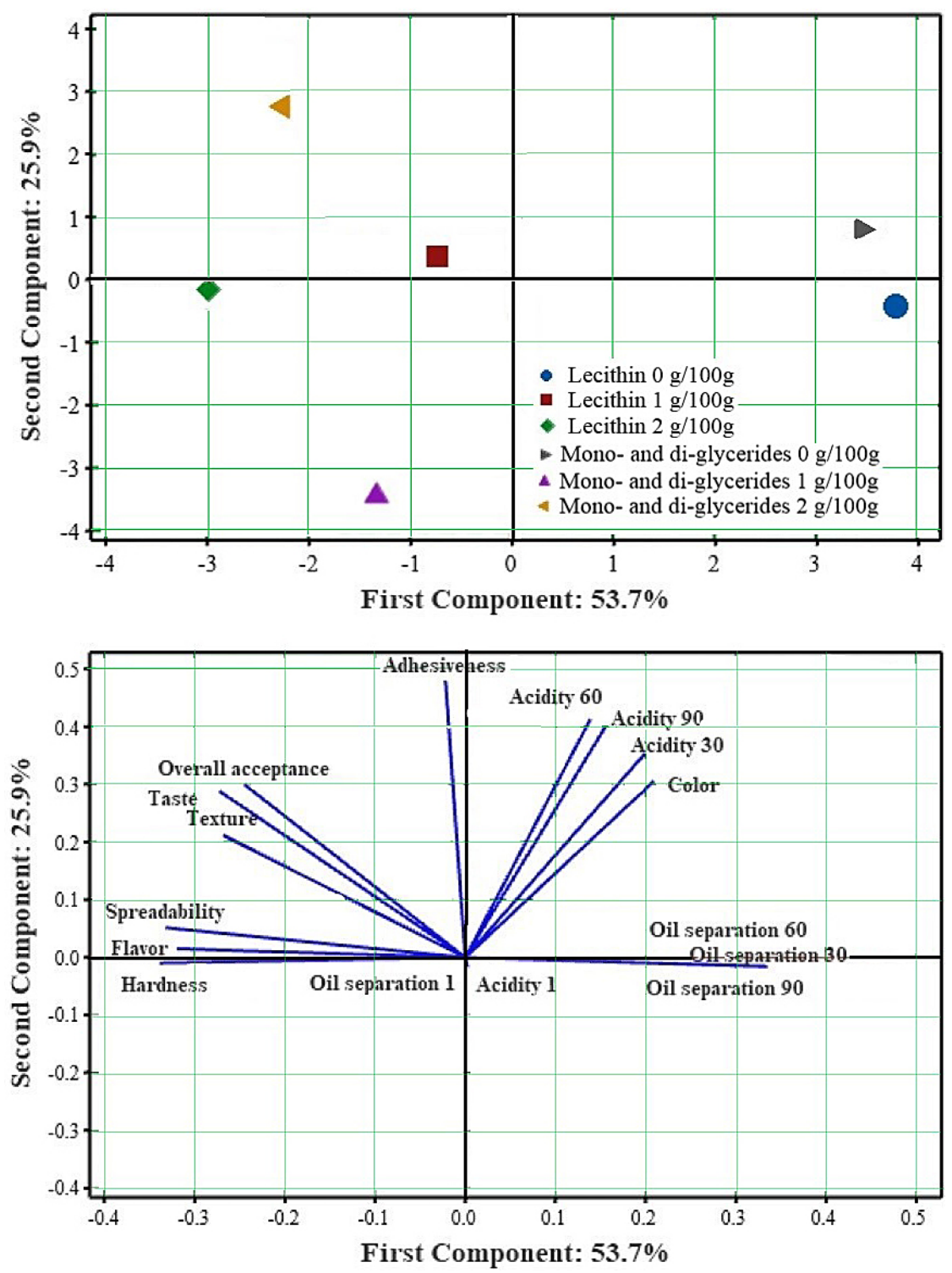

FIGURE 1. Biplot of principal component analysis of hazelnut butters containing lecithin and mono and di-glycerides and without emulsifiers. Variables are sensory characteristics (taste, flavor, texture, color, spreadability, and overall acceptance), texture parameters (hardness and adhesiveness), and quality properties (acidity and oil separation on day 1, 30, 60, and 90 of storage). 
TABLE 7. Partial least squares regression (PLSR) models for sensory characteristics of hazelnut butters containing lecithin and mono- and di-glycerides.

\begin{tabular}{|c|c|c|}
\hline $\begin{array}{l}\text { Sensory } \\
\text { attribute }\end{array}$ & Multiple regression equation & $\mathrm{R}^{2}$ \\
\hline Taste & $\begin{aligned}-3.84 & +0.86 \text { Hardness }+1.94 \text { Adhesiveness } \\
& +0.65 \text { Acidity } 30-0.029 \text { O.S.30 }\end{aligned}$ & 99.92 \\
\hline Flavor & $\begin{array}{c}-3.49+1.32 \text { Hardness }-1.25 \text { Adhesiveness } \\
+2.81 \text { Acidity } 30+0.014 \text { O.S.30 }\end{array}$ & 98.96 \\
\hline Texture & $\begin{aligned}-45.04 & +7.78 \text { Hardness }+0.96 \text { Adhesiveness } \\
& +5.28 \text { Acidity } 30+0.41 \text { O.S. } 30\end{aligned}$ & 94.90 \\
\hline Color & $\begin{array}{c}0.39+0.43 \text { Hardness }+0.95 \text { Adhesiveness } \\
-0.25 \text { Acidity } 30+0.063 \text { O.S.30 }\end{array}$ & 96.92 \\
\hline Spreadability & $\begin{array}{c}-6.28+1.78 \text { Hardness }-1.36 \text { Adhesiveness } \\
+3.89 \text { Acidity } 30-0.056 \text { O.S.30 }\end{array}$ & 99.97 \\
\hline $\begin{array}{l}\text { Overall } \\
\text { acceptance }\end{array}$ & $\begin{aligned}-32.92 & +5.58 \text { Hardness }+1.61 \text { Adhesiveness } \\
& +5.02 \text { Acidity } 30+0.26 \text { O.S.30 }\end{aligned}$ & 94.73 \\
\hline
\end{tabular}

O.S.30: Oil separation on day 30 of hazelnut butter storage; $R^{2}$ : multiple determination coefficient.

The high coefficients of multiple determination $(94.73 \%-$ $-99.97 \%$ ) provide evidence for the applicability of PLSR model within the ranges of the variables involved.

\section{CONCLUSIONS}

Generally, the results of the present research showed that the hazelnut butter could be a good food product to increase the consumption of nutritious hazelnuts. The lecithin and mono- and di-glycerides as emulsifiers had no negative effect on the sensory characteristics and texture parameters of hazelnut butter. Both emulsifiers improved hazelnut butter stability. By optimizing the physicochemical properties and sensory characteristics of hazelnut butter, the best qualitative, sensory, and shelf life properties were observed in the samples containing lecithin at the level of $2 \mathrm{~g} / 100 \mathrm{~g}$ and mono- and di-glycerides at the level of $1 \mathrm{~g} / 100 \mathrm{~g}$. Moreover, the sensory characteristics was significantly positively correlated with hardness and negatively with oil separation during storage. These findings were confirmed by PCA results. Combining the sensory scores and data of instrumental measurements in the PLSR analysis provided a valuable insight for predicting the effect of physicochemical properties on the sensory characteristics of hazelnut butters. In future study, the effect of other factors such as hazelnut roasting, content of antioxidants and sweeteners on the hazelnut butter quality, stability, and marketing can be considered.

\section{ACKNOWLEDGEMENTS}

The Department of Food Science and Technology at University of Guilan is warmly acknowledged for providing necessary research facilities.

\section{RESEARCH FUNDING}

Partial support for this research was provided by the Guilan Science and Technology Park under creativity project number 97/7145.

\section{CONFLICT OF INTEREST}

The authors declare no conflict of interest.

\section{ORCID IDS}

A. Pourfarzad https://orcid.org/0000-0003-2913-9682

\section{REFERENCES}

1. Akcicek, E., Otles, S., Esiyok, D. (2005). Cancer and its prevention by some horticultural and field crops in Turkey. Asian Pacific Journal of Cancer Prevention, 6, 224-230.

2. AOAC. (2005). Official methods of analysis of AOAC International. In: Association of Official Analytical Chemists, Washington, DC.

3. Ardakani, A.S., Shahedi, M., Kabir, G. (2009). Optimizing formulation of pistachio butter production. Journal of Science and Technology of Agriculture and Natural Resources, $13(47$ (A)), 49-60.

4. Ascari, L., Siniscalco, C., Palestini, G., Lisperguer, M.J., Huerta, E.S., De Gregorio, T., Bregaglio, S. (2020). Relationships between yield and pollen concentrations in Chilean hazelnut orchards. European Journal of Agronomy, 115, art. no. 126036. https://doi.org/10.1016/j.eja.2020.126036

5. Capurso, A., Crepaldi, G., Capurso, C. (2018). Nuts. In: Capurso, A., Crepaldi, G., Capurso, C. (Eds.) Benefits of the Mediterranean Diet in the Elderly Patient, Springer, pp. 263-284.

https://doi.org/10.1007/978-3-319-78084-9_11

6. Deng, Y., Peng, C., Dai, M., Lin, D., Ali, I., Alhewairini, S.S., Zheng, X., Chen, G., Li, J., Naz, I. (2020). Recent development of super-wettable materials and their applications in oil-water separation. Journal of Cleaner Production, 266, art. no. 121624. https://doi.org/10.1016/j.jclepro.2020.121624.

7. Dobhal, K., Singh, N., Semwal, A., Negi, A. (2018). A brief review on hazelnuts. Internationl Journal of Recent Scientific Research, 9(1), 23680-23684.

http://dx.doi.org/10.24327/ijrsr.2018.0901.1515

8. Ereifej, K., Rababah, T., Al-Rababah, M. (2005). Quality attributes of halva by utilization of proteins, non-hydrogenated palm oil, emulsifiers, gum arabic, sucrose, and calcium chloride. International Journal of Food Properties, 8(3), 415-422. https://doi.org/10.1080/10942910500267323

9. Eudier, H., Ben-Harb, S., Lorand, J.-P., Duthil, F., Negahban, M., Saiter, J.-M., Chan-Huot, M. (2020). Properties of an analogue cheese obtained from raw peanut. Peanut Science, 47(2), 81-88.

https://doi.org/10.3146/PS20-1.1

10. FAOSTAT. (2020). FAO Statistics, Food and Agriculture Organization of the United Nations. In: Rome, Italy.

11. Garcia, J., Agar, I., Streif, J. (1994). Lipid characteristics of kernels from different hazelnut varieties. Turkish Journal of Agricultural and Forestry, 18, 199-202.

12. Gills, L.A., Resurreccion, A.V.A. (2000a). Overall acceptability and sensory profiles of unstabilized peanut butter and peanut butter stabilized with palm oil. Journal of Food Processing and Preservation, 24(6), 495-516.

https://doi.org/10.1111/j.1745-4549.2000.tb00437.x 
13. Gills, L.A., Resurreccion, A.V.A. (2000b). Sensory and physical properties of peanut butter treated with palm oil and hydrogenated vegetable oil to prevent oil separation. Journal of Food Science, 65(1), 173-180.

https://doi.org/10.1111/j.1365-2621.2000.tb15975.x

14. Godoy, J.L., Vega, J.R., Marchetti, J.L. (2014). Relationships between PCA and PLS-regression. Chemometrics and Intelligent Laboratory Systems, 130, 182-191.

https://doi.org/10.1016/j.chemolab.2013.11.008

15. Haghani Haghighi, H., Azar, M., Mazloumi, M.T., Komeyli Fonoud, R. (2008). Survey of formulation, production and sensory evaluation of pistachio butter. Iranian Journal of Food Science and Technology, 5(3), 19-26 (in Persian).

16. Hejri-Zarifi, S., Ahmadian-Kouchaksaraei, Z., Pourfarzad, A., Khodaparast, M.H.H. (2013). Dough performance, quality and shelf life of flat bread supplemented with fractions of germinated date seed. Journal of Food Science and Technology, 51 (12), 3776-3784.

https://doi.org/10.1007/s13197-013-0929-7

17. Huynh, N.N., Chin-Dusting, J. (2006). Amino acids, arginase and nitric oxide in vascular health. Clinical and Experimental Pharmacology and Physiology, 33(1-2), 1-8. https://doi.org/10.1111/j.1440-1681.2006.04316.x

18. Izidoro, D.R., Scheer, A. de P., Sierakowsk, M.-R. (2009). Rheological properties of emulsions stabilized by green banana (Musa cavendishii) pulp fitted by power law model. Brazilian Archives of Biology and Technology, 52(6), 1541-1553.

https://doi.org/10.1590/S1516-89132009000600026

19. Martens, H., Martens, M. (2001). Analysis of two data tables $X$ and Y: Partial Least Squares Regression (PLSR). In Multivariate Analysis of Quality: An Introduction. Wiley \& Sons Ltd., London, UK, pp. 111-125.

20. Mirtajeddini, S.B., Azadmard-Damirchi, S., Peighambardoust, S.H., Rasouli-Pirouzian, H. (2016). Application of ester monodiglycerid citric acid (Citrem) in replacement of lecithin, on some qualitative characteristics of milk chocolate. Journal of Food Research, 26(2), 265-276 (in Persian).

21. Pellegrino, R., Cheon, B.K., Forde, C.G., Oleszkiewicz, A., Pieniak, M., Luckett, C.R. (2020). The contribution of texture contrasts and combinations to food acceptance across cultures. Journal of Texture Studies, 51 (2), 225-231.

https://doi.org/10.1111/jtxs.12494

22. Pourfarzad, A., Ahmadian, Z., Tavassoli-Kafrani, M.H. (2019). The effect of sodium stearoyl lactylate on structural changes of wheat gluten in a model system fortified with inulin: Investigation with Fourier transform infrared spectroscopy. Bioactive Carbohydrates and Dietary Fibre, 17, art. no. 100175.

https://doi.org/10.1016/j.bcdf.2018.12.001

23. Pourfarzad, A., Gheibi, S., Ahmadian, Z. (2016). Evaluation of sensory characteristics and modeling of the kinetics of hazelnut color indices during infrared roasting. Innovative Food Technologies, 4(2), 81-99.

24. Pourfarzad, A., Gheibi, S., Ahmadian, Z. (2018). Effect of different roasting methods, blanching and pasteurization conditions on physicochemical and sensory characteristics of hazelnut milk. Innovative Food Technologies, 5(2), 301-318.

25. Pourfarzad, A., Habibi-Najafi, M.B. (2012). Optimization of a liquid improver for barbari bread: staling kinetics and rela- tionship of texture with dough rheology and image characteristics. Journal of Texture Studies, 43(6), 484-493.

https://doi.org/10.1111/j.1745-4603.2012.00362.x

26. Pourfarzad, A., Haddad Khodaparast, M., Karimi, M., Mortazavi, S. (2014). Optimization of a novel improver gel formulation for Barbari flat bread using response surface methodology. Journal of Food Science and Technology, 51 (10), 2344-2356.

https://doi.org/10.1007/s13197-012-0778-9

27. Pourfarzad, A., Mehrpour, G.R. (2017). Health benefits of hazelnut. EC Nutrition, 8, 101-105.

28. Pourfarzad, A., Mohebbi, M., Mazaheri-Tehrani, M. (2012). Interrelationship between image, dough and Barbari bread characteristics; use of image analysis to predict rheology, quality and shelf life. International Journal of Food Science \& Technology, 47(7), 1354-1360.

https://doi.org/10.1111/j.1365-2621.2012.2980.x

29. Qaziyani, S.D., Pourfarzad, A., Gheibi, S., Nasiraie, L.R. (2019). Effect of encapsulation and wall material on the probiotic survival and physicochemical properties of synbiotic chewing gum: study with univariate and multivariate analyses. Heliyon, 5(7), art. no. e02144.

https://doi.org/10.1016/j.heliyon.2019.e02144

30. Ros, E. (2010). Health benefits of nut consumption. Nutrients, 2(7), 652-682.

https://doi.org/10.3390/nu2070652

31. Sabanis, D., Soukoulis, C., Tzia, C. (2009). Effect of raisin juice addition on bread produced from different wheat cultivars. Food Science and Technology International, 15(4), 325-336. https://doi.org/10.1177/1082013209346581

32. Said, A., Nasir, N.A. M., Bakar, C.A.A., Mohamad, W.A.F.W. (2019). Chocolate spread emulsion: Effects of varying oil types on physico-chemical properties, sensory qualities and storage stability. Journal of Agrobiotechnology, 10(2), 32-42.

33. Saker Ardakani, A. (2007). Study on the possibility of utilization sunflower and sesame pastes in the formulation of pistachio butter Iranian Food Science and Technology Research Journal, 3(1), 1-6.

34. San Martín, E., Avenoza, A., Peregrina, J.M., Busto, J.H. (2020). Solvent-based strategy improves the direct determination of key parameters in edible fats and oils by $1 \mathrm{H}$ NMR. Journal of the Science of Food and Agriculture, 100(4), 1726-1734.

https://doi.org/10.1002/jsfa.10193

35. Stuetz, W., Schlörmann, W., Glei, M. (2017). B-vitamins, carotenoids and $\alpha$ - $/ \gamma$-tocopherol in raw and roasted nuts. Food Chemistry, 221, 222-227.

https://doi.org/10.1016/j.foodchem.2016.10.065

36. Taş, N.G., Gökmen, V. (2015). Profiling triacylglycerols, fatty acids and tocopherols in hazelnut varieties grown in Turkey. Journal of Food Composition and Analysis, 44, 115-121. https://doi.org/10.1016/j.jfca.2015.08.010

37. Taş, N.G., Gökmen, V. (2018). Profiling of the contents of amino acids, water-soluble vitamins, minerals, sugars and organic acids in Turkish hazelnut varieties. Polish Journal of Food and Nutrition Sciences, 68(3), 223-234.

https://doi.org/10.1515/pjfns-2018-0002

38. Tipping, M.E., Bishop, C.M. (1999). Probabilistic principal component analysis. Journal of the Royal Statistical Society: Series B (Statistical Methodology), 61(3), 611-622. https://doi.org/10.1111/1467-9868.00196 
39. Totlani, V., Chinnan, M. (2007). Effect of stabilizer levels and storage conditions on texture and viscosity of peanut butter. Peanut Science, 34(1), 1-9.

https://doi.org/10.3146/0095-3679(2007)34[1:EOSLAS]2.0.CO;2

40. Turan, G.Y.M., Akccedil, F. (2011). The importance of Turkish hazelnut trace and heavy metal contents for human nutrition. Journal of Soil Science and Environmental Management, 2(1), 25-33.

41. USDA. (2015). National nutrient database for standard reference, release 28. United States Department of Agriculture Beltsville.
42. Villarroel, M., Biolly, E., San Martin, S., Estrada, G. (1993). Chilean hazelnut butter, a new alternative for consumers. Plant Foods for Human Nutrition, 44(2), 131-136.

https://doi.org/10.1007/BF01088377

Submitted: 19 June 2020. Revised: 16 September, 11 October, and 29 October 2020. Accepted: 2 November 2020. Published online: 9 December 2020. 